\title{
环糊精超分子组装体与核酸的相互作用
}

\author{
陈湧刘 育*
}

(南开大学化学系 元素有机化学国家重点实验室 天津 300071)

\begin{abstract}
摘要 环糊精是一类由 $6 \sim 8$ 个 $D$-型葡萄糖连接而成的环聚多糖分子, 目前已广泛应用于化学和生物学的许多领域. 综 述了一些生物活性的环糊精超分子组装体，如环糊精假聚轮烷、环糊精/金纳米粒子组装体、环糊精/富勒烯组装体、环 糊精/碳纳米管组装体等的构筑及其与核酸的相互作用，如对核酸的切割、凝聚、传递作用和对核酸酶的抑制作用等方 面的研究进展.
\end{abstract}

关键词 环糊精; 核酸; 超分子组装体

\section{Supramolecular Assembly of Cyclodextrins and Its Interactions with Nucleic Acid}

\author{
Chen, Yong Liu, Yu* \\ (State Key Laboratory of Elemento-Organic Chemistry, Department of Chemistry, Nankai University, Tianjin 300071)
}

\begin{abstract}
Cyclodextrins (CDs) are a class of cyclic oligosaccharides with six to eight $D$-glucose units and widely applied in many fields of chemistry and biology. This review deals with the representative contributions in the construction of some bioactive cyclodextrin-based supramolecular assemblies, including cyclodextrin polypseudorotaxane, cyclodextrin/gold nanoparticle assembly, cyclodextrin/fullerene assembly, cyclodextrin/carbon nanotube assembly, and their interactions with nucleic acids, including the nucleic acid cleavage, condensation, delivery and the inhibition of nucleic acid enzymes.
\end{abstract}

Keywords cyclodextrin; nucleic acid; supramolecular assembly

作为超分子化学研究中最重要的主体化合物之一, 由 $D$-型吡喃萄葡糖以 1,4 -糖苷键首尾相连形成的环聚 多糖分子——环糊精(cyclodextrin), 具有疏水的内腔和 亲水的外壁. 其特有的疏水空腔不仅可以识别多种有 机、无机和生物分子或离子形成主-客体包结配合物或 超分子复合物, 而且能够通过高分子链或有机分子的模 板作用组装成轮烷、纳米线、纳米管等有序高级结构, 因 此作为一种优良的酶-底物相互作用模型和分子器件/分 子机器的构筑单元被广泛应用于科学和技术的许多领 域 ${ }^{[1 \sim 5]}$. 环糊精是淀粉经环糊精葡萄糖基转移酶催化降 解得到的, 最常见的 $\alpha-, \beta$-和 $\gamma$-环糊精分别由 6,7 和 8 个 葡萄糖单元构成(图 1). 经化学修饰后的环糊精相比于 天然环糊精显示出更高的分子键合能力和选择性. 而通 过分子组装的方法将多个修饰环糊精单元以非共价相 互作用结合在一起形成的环糊精超分子组装体, 一方面
其拥有的多个环糊精空腔能够通过协同键合实现与底 物分子的高稳定性结合; 另一方面，环糊精超分子体系 中功能修饰基团可以同时与底物中不同的作用位点发 生相互作用. 本文将简要介绍近年来在具有核酸作用活 性的环糊精超分子组装体方面的一些研究进展. 将环糊 精组装体与核酸相结合的优势在于: 一方面环糊精具有 良好的水溶性、较高的生物相容性和较低的毒性，且环 糊精空腔能够有效键合核酸中的碱基单元，有利于其作 为核酸等生物大分子的载体; 另一方面, 环糊精组装体 与核酸的结合使得环糊精组装体上的众多功能基团能 够与核酸上的多重键合位点(如核酸碱基、磷酸根负离 子等)通过范德华力、疏水相互作用、氢键、静电相互 作用等发生协同键合，从而实现环糊精组装体与核酸之 间的 “多位点、多模式” 的作用方式.

\footnotetext{
*E-mail: yuliu@nankai.edu.cn; Tel.: 022-23503625; Fax: 022-23503625.

Received January 12, 2012; revised March 7, 2012; published online March 23, 2012.

Project supported by the 973 Program (No. 2011CB932500) and the National Natural Science Foundation of China (Nos. 20932004, 91027007). 973 重大研究计划(No. 2011CB932500)和国家自然科学基金(Nos. 20932004, 91027007)资助项目.
} 

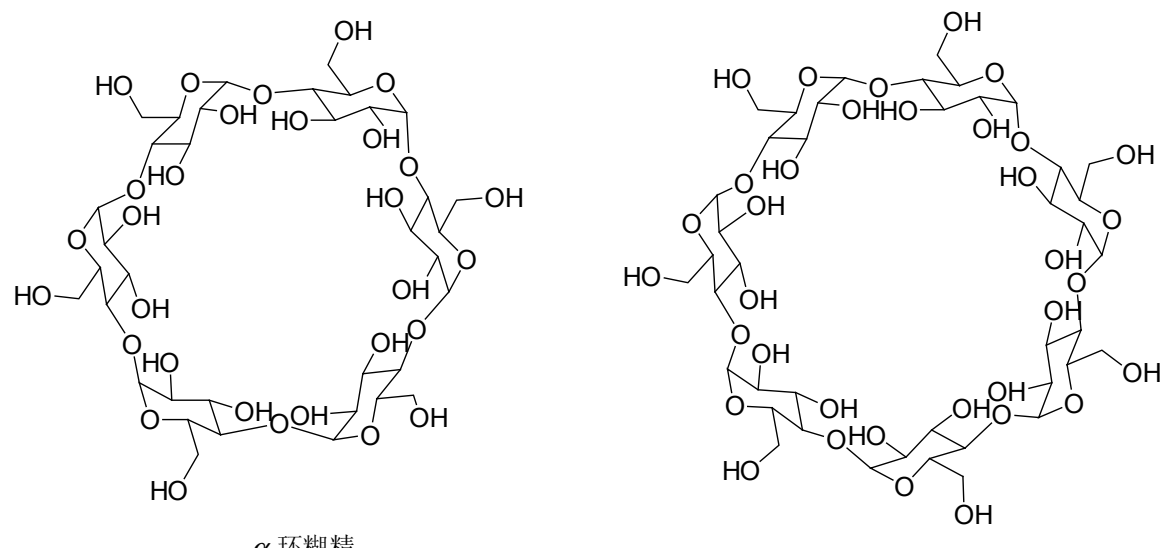

$\alpha$-环糊精

$\beta$-环糊精

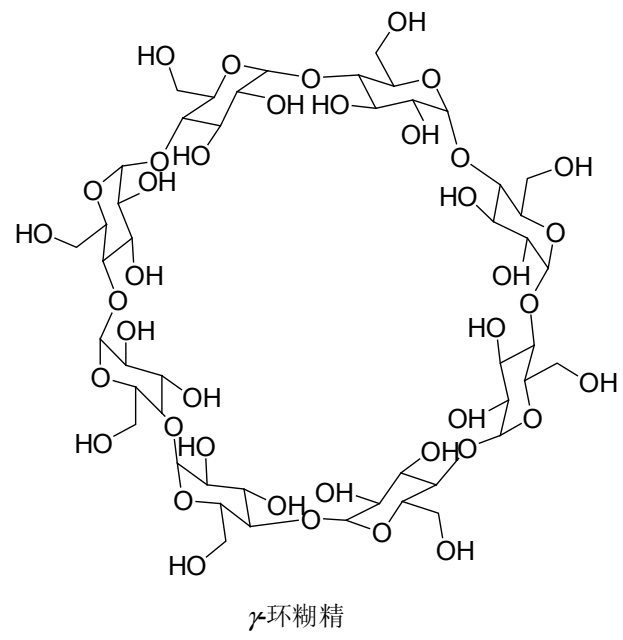

图 $1 \alpha-, \beta$-和 $\gamma$-环糊精的结构示意图

Figure 1 Structures of $\alpha$-, $\beta$ - and $\gamma$-cyclodextrins

\section{1 环糊精超分子组装体对核酸的切割作用}

DNA 切割试剂不仅对研究 DNA 分裂，修复及信号 转导机制有很大帮助, 而且许多切割试剂可能作为潜在 的抗癌药物. 因此 DNA 切割试剂的研究一直是生物化 学中最为活跃的前沿领域之一. 在众多的 DNA 切割试 剂中, 富勒烯是一种具有优良生物性能和低毒性的物 质. 然而, 其在水溶液中极低的溶解度大大限制了它在 生物领域的应用. 近年来, 我们通过环糊精与富勒烯的 组装构筑了具有 DNA 切割功能的水溶性超分子组装体. 例如, 通过邻苯二硒桥连双 $\beta$-环糊精的 $\operatorname{Pt}(\mathrm{IV})$ 配合物与 $\mathrm{C}_{60}$ 在甲苯/DMF 混合溶剂中反应能够获得一种新型的 环糊精/富勒烯超分子组装体(图 2) ${ }^{[6]}$. 隧道扫描显微镜 (STM)研究表明邻苯二硒桥连双 $\beta$-环糊精的 $\operatorname{Pt}(\mathrm{IV})$ 配合 物在石墨表面形成了规则的预组织结构. 隧道扫描显微 镜(STM)和透射电子显微镜(TEM) 表明, 通过相邻的桥 连环糊精中的两个 $\beta$-环糊精空腔协同键合一个 $\mathrm{C}_{60}$ 分子, 该组装体在溶液中形成了宽 $1.8 \mathrm{~nm}$, 高 $1.9 \mathrm{~nm}$, 平均长 度为 $150 \sim 200 \mathrm{~nm}$ 的线状结构. 每个组装体中含有 $60 \sim$
80 个桥连环糊精单元, 其平均分子量约为 $250 \mathrm{~kg} \cdot \mathrm{mol}^{-1}$. 组装体的水溶性为 $7 \mathrm{mg} / \mathrm{mL}$ (以 $\mathrm{C}_{60}$ 片断计算), 明显高于 天然 $\beta$-环糊精与 $\mathrm{C}_{60}$ 形成的 $2: 1$ 包结配合物 $(4 \mathrm{mg} / \mathrm{mL})$. 有意义的是，当选择质粒 DNA 作为底物时，组装体显 示在可见光照射下切割 DNA 的能力, 能够将闭合的超 螺旋 DNA 切割为带有缺口的环状 DNA. 其机理可能是 由于在与 DNA 发生作用时, 组装体中的 $\mathrm{C}_{60}$ 与 DNA 中 的鸟苷部分相互靠近. 在可见光照射下，单线态氧被 $\mathrm{C}_{60}$ 的光激发所激活. 进而，被激活的单线态氧与 DNA 中的鸟苷部分发生 $[4+2]$ 或 $[2+2]$ 的环加成反应，导致 DNA 的断裂.

另一方面，金纳米粒子也具有广阔的生物材料应用 前景. 利用颈基与金的强化学吸附作用, 将环糊精与聚 丙二醇形成的假聚轮烷结合在金纳米粒子上, 可以获得 一类新型的水溶性环糊精假聚轮烷/金纳米粒子超分子 组装体(图 3) ${ }^{[7]}$. TEM 研究表明, 将颈基环糊精吸附到单 个金纳米粒子上形成的组装体的平均直径仅为 $(4.8 \pm$ 2.1) $\mathrm{nm}$, 然而假聚轮烷与金纳米粒子形成的超分子组 
(a)

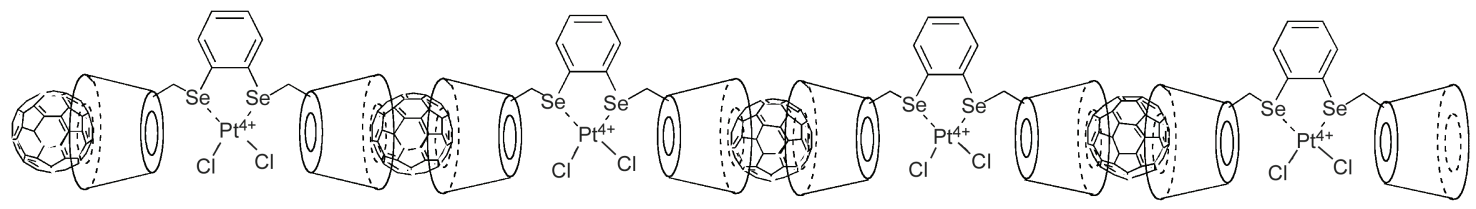

(b)

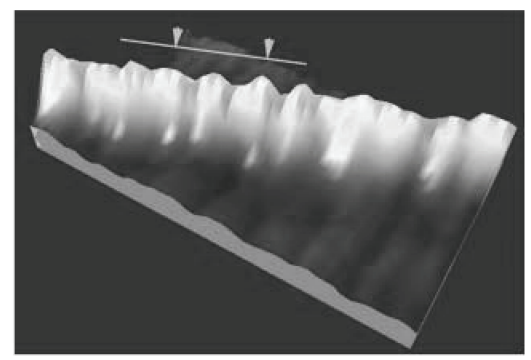

(c)

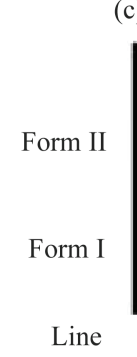

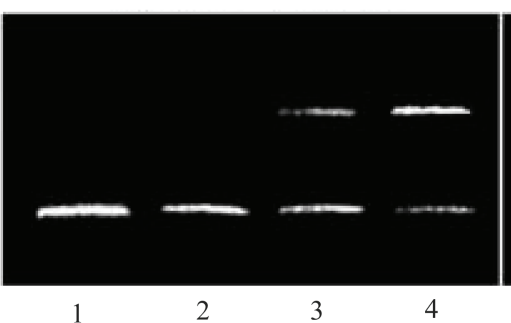

in the dark

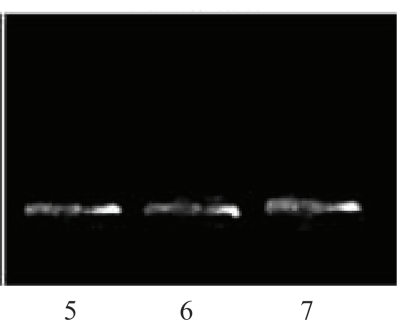

图 2 由邻苯二硒桥连环糊精与 $\mathrm{C}_{60}$ 构筑的线状超分子组装体的(a)结构示意图、(b) STM 图像和(c) DNA 凝胶电泳图

Figure 2 (a) Structure of supramolecular assembly formed by bridged biscyclodextrin and $\mathrm{C}_{60}$, (b) STM image and (c) agarose gel electrophoretic patterns of DNA and nicked DNA

Line 1: no reagent in Tris-HCl buffer ( $\mathrm{pH}$ 7.4); lines 2 and 5: with biscyclodextrin; lines 3 and 6: with Pt(II)-coordinated biscyclodextrin; lines 4 and 7: with supramolecular assembly

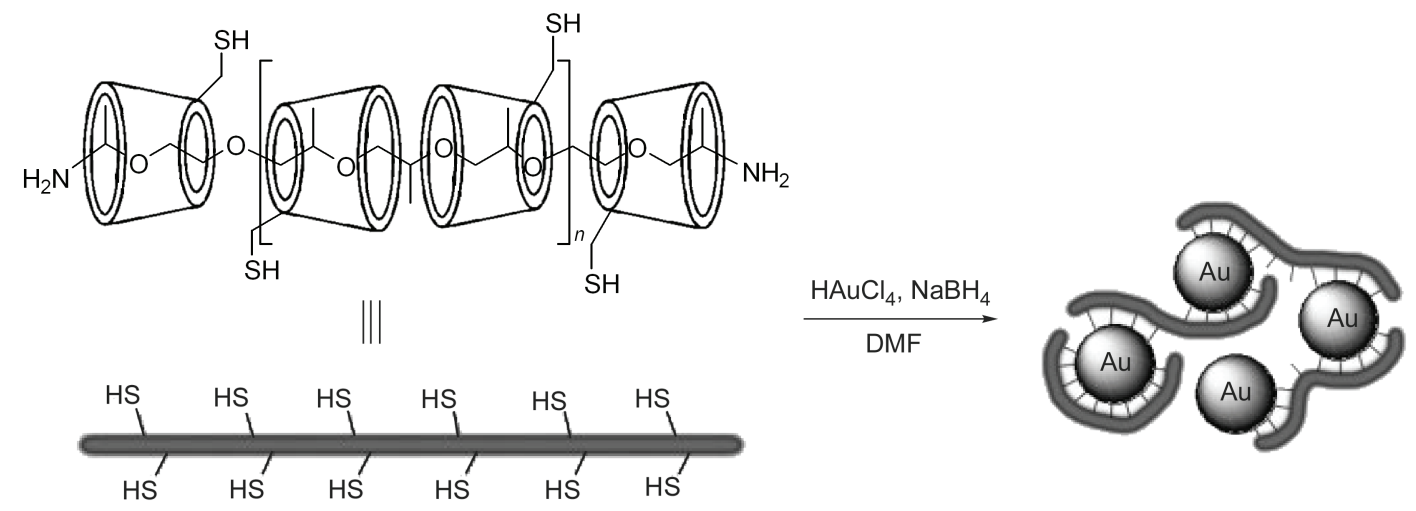

图 3 由巯基环糊精假聚轮烷和金纳米粒子构筑的超分子组装体

Figure 3 Supramolecular assembly constructed by thiocyclodextrin pseudopolyrotaxane and gold nanoparticles

装体的直径则增加到 $(70 \pm 10) \mathrm{nm}$, 证明多条假聚轮烷 与多个金纳米粒子发生了聚集. 环糊精假聚轮烷/金纳 米粒子超分子组装体与 Chakravarty 等 ${ }^{[8]}$ 报道的 $\mathrm{Cu}-\mathrm{S}$ 配 合物的光诱导 DNA 切割机理相似, 也是通过 $\mathrm{Au}-\mathrm{S}$ 之间 的电荷转移和 $\mathrm{Au}$ 的 $\mathrm{d}-\mathrm{d}$ 轨道激发以及单线态氧自由基 的生成, 显示出在可见光激发下切割 DNA 的能力.

将环糊精假聚轮烷的两端连接到金纳米粒子上, 则 可以获得另一种水溶性环糊精假聚轮烷/金纳米粒子超 分子组装体(图 4) ${ }^{[9]}$. 该组装体呈现出一种三维笼状结 构, 其中笼的各个顶点由金纳米粒子构成, 而连接臂则 由环糊精假聚轮烷构成. 当改变作为环糊精假聚轮烷构 筑模板的聚丙二醇链的长度时, 可以实现对超分子笼尺 寸的有效调控. 例如, 当选取平均分子量为 400, 2000 和 4000 的聚丙二醇作为模板时, 分别有 3, 12 和 25 个环糊 精单元穿插到聚丙二醇模板上形成环糊精假聚轮烷. 进 而, 由这些环糊精假聚轮烷与金纳米粒子进行组装所获
得的超分子笼的平均直径为 200,400 和 $800 \mathrm{~nm}$, 而同样 条件下制备的单个金纳米粒子的平均直径仅为(19.5土 3.4) $\mathrm{nm}$. 更为有意义的是，当选用带有功能基团的环糊 精衍生物作为构筑单元时, 这些功能基团会富集在超分 子笼中众多孔洞的内壁上，使得超分子笼具有对一些特 定分子的识别和捕获能力. 例如, 当选用色氨酸修饰环 糊精、平均分子量为 2000 的聚丙二醇和金纳米粒子作 为构筑单元时, 所获得的超分子笼显示出在水溶液中捕 获 $\mathrm{C}_{60}$ 的能力. 溶解性实验 ${ }^{[10,11]}$ 表明, $1 \mathrm{mg}$ 超分子笼在 1 $\mathrm{mL}$ 水中能够捕获 $1.83 \mathrm{mg} \mathrm{C} 60$. 而由天然环糊精在相同 条件下组装成的超分子笼仅能捕获 $0.08 \mathrm{mg} \mathrm{C}_{60}$. 当选择 质粒 DNA 作为底物时, 未结合 $\mathrm{C}_{60}$ 的超分子笼仅显示出 较弱的 DNA 切割能力. 在结合了 $\mathrm{C}_{60}$ 之后, 超分子笼则 显示出很好的光诱导切割 DNA 的能力, 能够在可见光 照射下将大部分闭合的超螺旋 DNA 转化为带有缺口的 DNA. 


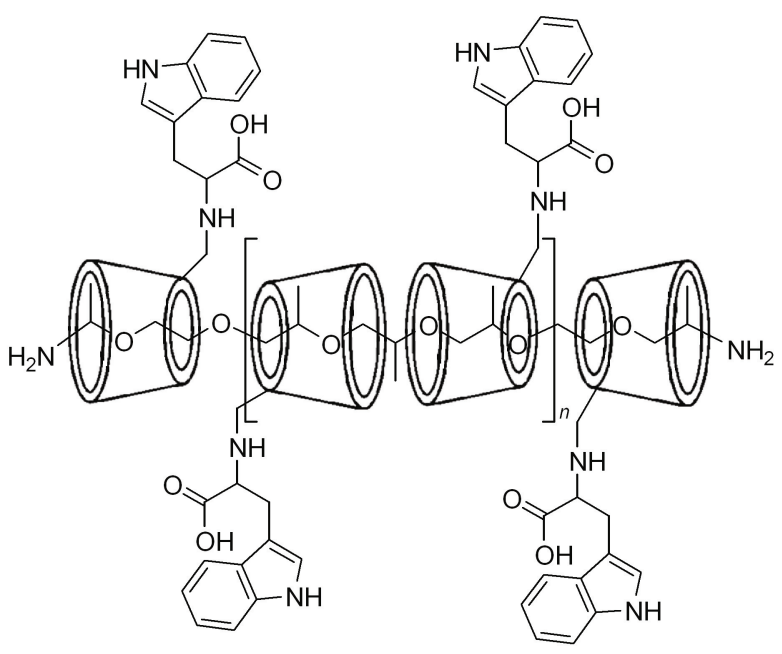

L-try-CD-based polypseudorotaxane

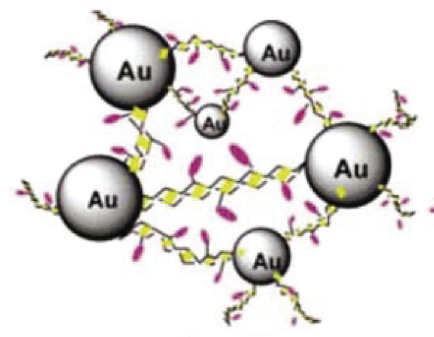

nanocage

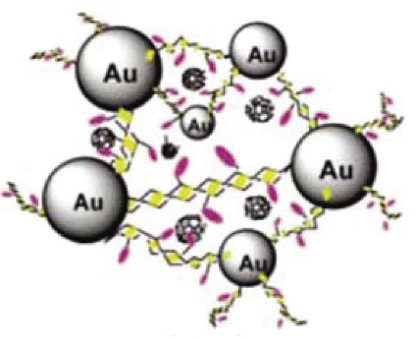

$\mathrm{C}_{60}$-saturated nanocage
图 4 色氨酸修饰环糊精假聚轮烷、超分子笼和捕获了 $\mathrm{C}_{60}$ 的 超分子笼结构示意图

Figure 4 Structures of $L$-try-cyclodextrin-based polypseuorotaxane, supramolecular cage and $\mathrm{C}_{60}$-saturated supramolecular cage

\section{2 环糊精组装体对核酸的凝聚作用}

DNA 凝聚是 DNA 传递和转染的前提条件, 细胞中 的 DNA 必须凝聚成特定结构后才能装载到细胞核中, 因此设计安全高效的 DNA 凝聚试剂具有重要的科学意 义. 近来, 关于环糊精假聚轮烷与 DNA 的相互作用引 起了人们的广泛关注. Stoddart 等 ${ }^{[12]}$ 用乳糖苷修饰环糊 精自组装的假聚轮烷抑制了半乳凝素-1 媒介的 $\mathrm{T}$ 细胞 凝集. Yui 等 ${ }^{[13,14]}$ 将二甲氨基乙基修饰环糊精自组装的 假聚轮烷应用于 pDNA 向细胞核的传递. $\mathrm{Li}$ 等 ${ }^{[15]}$ 将寡聚 乙烯二胺修饰环糊精穿线于高分子链构筑的阳离子化 环糊精聚轮烷用作基因传递的载体. 这些研究都是基于 环糊精超分子组装体中众多的正电荷与 DNA 链上的磷 酸根负电荷的相互作用. 在此基础上, 我们力图在环糊 精超分子组装体中引入对正电荷的调控因素, 以达到控 制 DNA 凝聚和传递的目的. 例如, 我们 ${ }^{[16,17]}$ 构筑了一 个以聚丙二醇(平均分子量 2000)为轴、已二胺修饰环糊 精以及环状分子葫芦䐂为轮的新型二维超分子线. 在这 个超分子组装体中, 环糊精上的已二胺修饰基由于在水
中发生质子化而带有正电荷, 可以对 DNA 产生凝聚作 用. 葫芦脲的空腔由腿羰基环绕而成, 腿羰基又形成了 阳离子键合位点, 可以通过偶极相互作用和与腿羰基形 成的氢键来结合有机分子的带电部分. 在这个二维超分 子线中，正是通过葫芦腿对环糊精上的己二胺正电荷的 有效键合来实现对 DNA 凝聚的调控的. 也就是说, 二 维超分子线上葫芦腿单元的数量能够显著地影响 DNA 的凝聚效果, 导致与 DNA 之间形成不同大小的凝聚颗 粒. 然而它们之间并不是一种简单的线性关系，只有当 $70 \%$ 的环糊精己二胺侧臂套入葫芦腿时, DNA 的凝聚效 果达到最佳(图 5). 有意义的是, 这种二维超分子线在碱 存在下可以转变成一维超分子线, 加入 $\alpha$-环糊精又可以 得到另外一种二维纳米线, 从而可以实现酸碱调控的二 维超分子线的转化. 这种通过超分子技术实现对 DNA 凝聚作用的调控对进一步设计基因传导药物的载体是 非常有意义的.

除正电荷外, 稠环芳烃也具有好的与 DNA 相互作 用的能力. Schneider 等 ${ }^{[18]}$ 的研究发现葱基修饰 $\beta$-环糊精 在水溶液中以自包结的模式存在，与 DNA 不发生作用; 在加入客体分子金刚烷醇后，被顶出环糊精空腔的萝基 却能够嵌入 DNA 的沟槽, 这可以看作是一个化学变构 启动 DNA 的模型体系. 从这一结果出发, 我们通过聚 丙二醇高分子链穿插葱基环糊精构筑了含稠环芳烃侧 链的假聚轮烷, 力图发挥组装体中众多葱修饰环糊精的 协同作用，构筑优良的超分子 DNA 凝聚体系 ${ }^{[19]}$. 通过 比较假聚轮烷核磁氢谱中聚丙二醇链上甲基质子的积 分强度 (一条聚丙二醇 2000 链上约含 34 个甲基)与葱基 环糊精上的 H-9 质子的积分强度 (一个葱基环糊精上含 1 个 H-9 质子), 可以确定一条假聚轮烷含有 $9 \sim 10$ 个葱基 环糊精单元(图 6). 苂光光谱滴定的结果表明假聚轮烷 中每个葱基环糊精单元与 DNA 的表观键合常数均达到

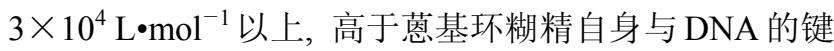
合常数(约 $9 \times 10^{3}{\mathrm{~L} \cdot \mathrm{mol}^{-1}}^{-1}$ ), 说明假聚轮烷较之单独的 葱基环糊精可以更好地结合 DNA. 分子动力学模拟研 究(图 7)表明, 葱基环糊精自身的蒽基修饰基倾向于嵌 入到 DNA 的小沟槽中, 而假聚轮烷中的葋基功能基能 够同时嵌入到双螺旋 DNA 的大沟槽和小沟槽中, 这也 是导致假聚轮烷与 DNA 更强键合的原因之一. 原子力 显微镜研究表明, 单独的葱基环糊精对小牛胸腺 DNA 没有任何凝聚作用，而假聚轮烷却能够有效地将原本为 松散线团的小牛胸腺 DNA 凝聚为直径为 $100 \mathrm{~nm}$ 的实心 粒子(图 7). DNA 凝聚的驱动力一方面来自于假聚轮烷 中众多的葱基环糊精与 DNA 沟槽的相互作用, 另一方 面则来自于假聚轮烷中部分质子化的氨基与负电荷的 DNA 磷酸根之间的静电相互作用. 


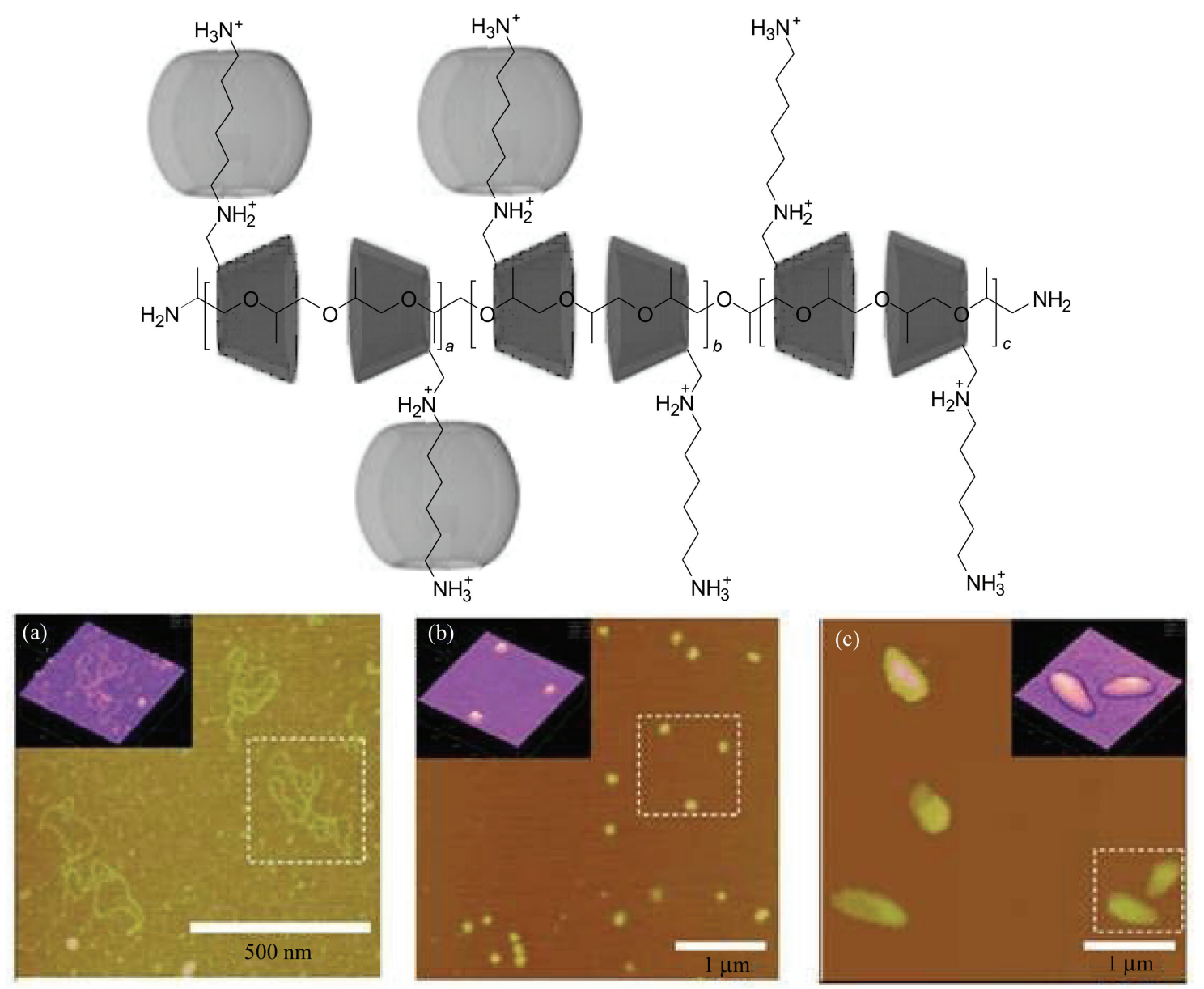

图 5 环糊精-葫芦脲二维超分子线的结构示意图和(a) DNA 自身及当存在(b) $0 \%$ 和(c) $70 \%$ 的葫芦 [6]腿时二维超分子线凝聚 DNA 后的 AFM 图像

Figure 5 Structures of cyclodextrin-cucurbituril 2D supramolecular linear array and AFM images of (a) free DNA in the presence of (b) $0 \%$ and (c) $70 \%$ of cucurbit[6]uril

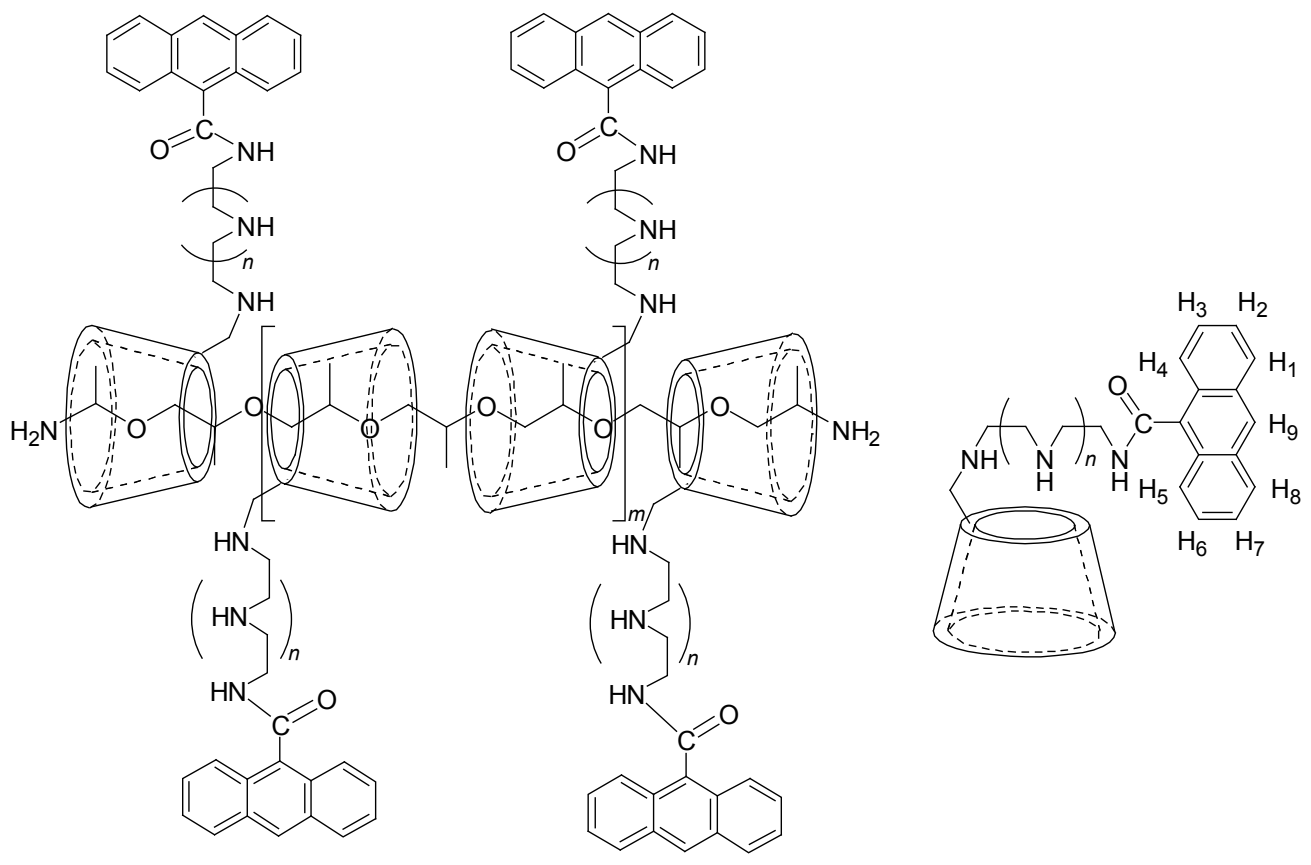

图 6 蒽基修饰 $\beta$-环糊精及假聚轮烷的结构示意图

Figure 6 Structures of anthryl-modified $\beta$-cyclodextrin and polypseudorotaxane 

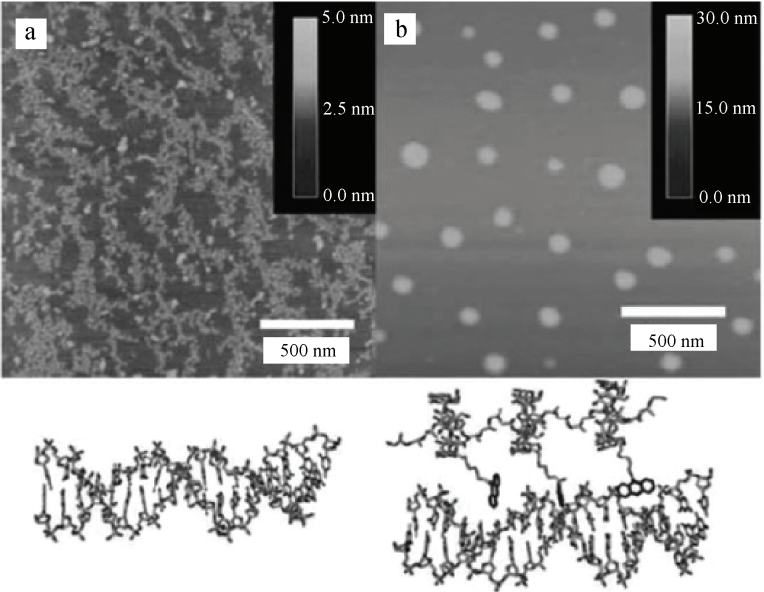

图 7 (a)小牛胸腺 DNA 自身和(b)小牛胸腺 DNA 被假聚轮烷 凝聚后的 AFM 图像

Figure 7 AFM images of calf thymus DNA before (a) and after (b) interacted with polypseudorotaxane

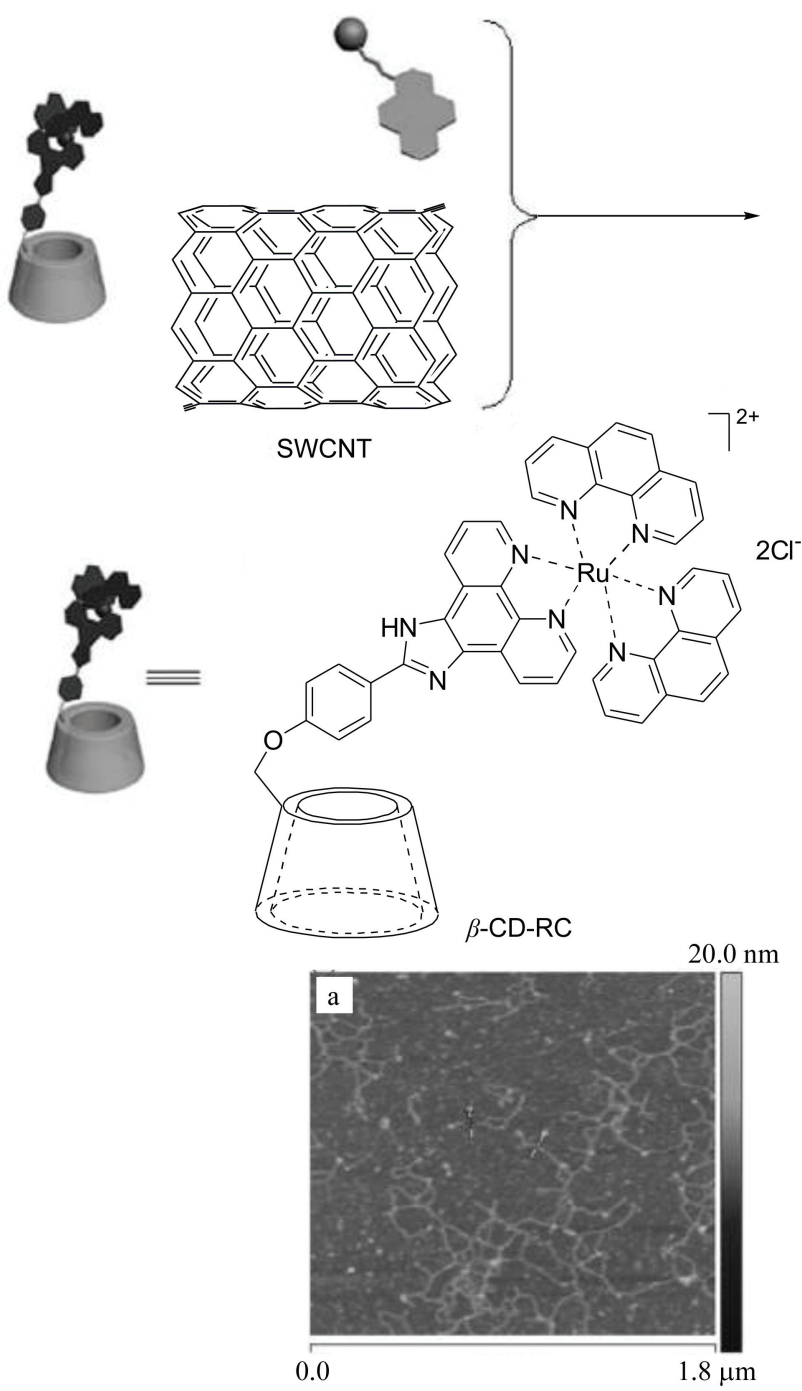

将具有 DNA 凝聚能力的超分子体系通过非共价相 互作用与碳纳米管相结合，可以得到一类新型的杂化超 分子组装体. 由于碳纳米管具有一维线性的特征, 因此 该类组装体有望实现在一维空间上对 DNA 的可控凝聚. 例如，通过环糊精空腔对金刚烷的强键合能力将环糊精 钌配合物与金刚烷基萠形成超分子复合物，再通过萠与 单壁碳纳米管之间的 $\pi-\pi$ 相互作用将萠基团贴附在单壁 碳纳米管的表面，这样就将正电性的环糊精钉配合物非 共价修饰到单壁碳纳米管的表面，从而得到一个结构新 颖的三元超分子体系(图 8) ${ }^{[20]}$. 在原子力显微镜图像中, 单臂碳纳米管的高度为 $0.9 \mathrm{~nm}$, 而修饰了环糊精的区域 增高至 $2.2 \mathrm{~nm}$, 自由的 DNA 则主要以环状超螺旋形式 存在. 当将超分子组装体与 DNA 结合后, DNA 被凝聚 为球状结构. 随着超分子组装体与 DNA 的重量比由 16 增加至 24, DNA 的球状凝聚体逐渐变为更为密实的粒

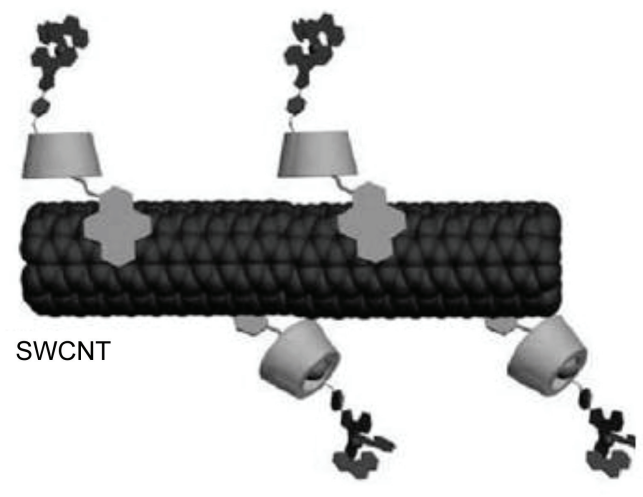

SWCNT Py-Ad $\beta-$ CD-RC
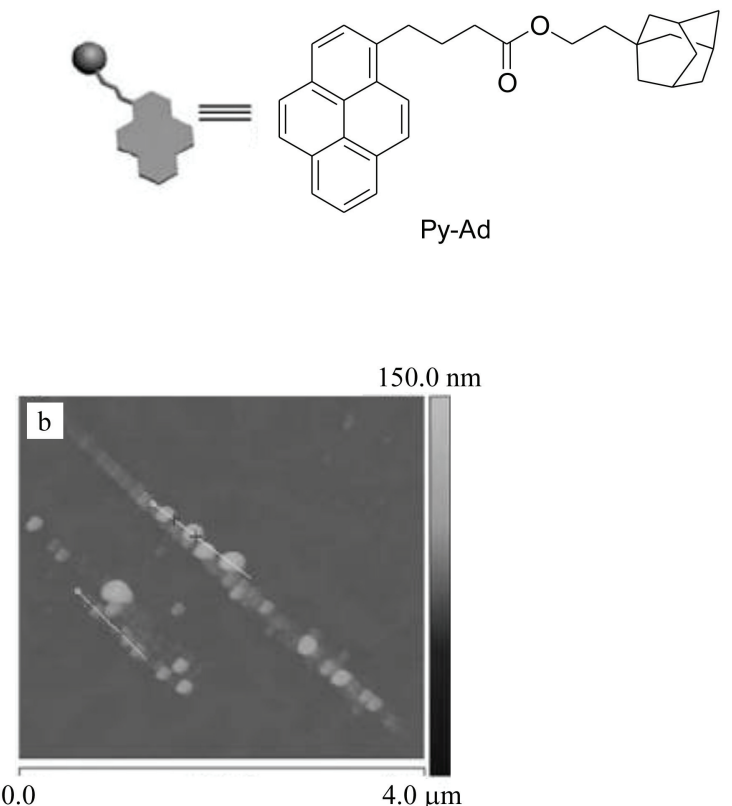

图 8 组装体及组装单元结构和(a)质粒 DNA 自身及(b)质粒 DNA 被环糊精钉配合物/金刚烷萠/碳纳米管复合物凝聚后的 AFM 图

Figure 8 Structures of molecular assembly and building blocks, and AFM images of DNA before (a) and after (b) interacted with molecular assembly 
子, 其高度也由 $50 \mathrm{~nm}$ 降至 $20 \mathrm{~nm}$, 且原子力显微镜图 像清晰地显示出 DNA 凝聚粒子沿碳纳米管方向的排列, 其机理应归属于 DNA 中磷酸二酯基团贴附到带正电荷 的碳纳米管表面 ${ }^{[21]}$. 更有意义的是, 当选用酵母细胞为 模型时, 苂光显微镜研究表明, 经超分子组装体与 DNA 的复合物处理后的细胞显示出明显的发光现象, 说明组 装体可以将 DNA 载入到细胞内.

除利用稠环芳烃对碳纳米管的贴附作用外, 还可以 利用疏水相互作用将环糊精组装体引入到碳纳米管上. 例如, 将环糊精连接到壳聚糖分子上, 利用壳聚糖衍生 物与碳纳米管之间的疏水相互作用, 可以将环糊精修饰 的壳聚糖缠绕到碳纳米管上形成超分子组装体(图 9) ${ }^{[22]}$. 通过核磁光谱的积分比可以计算出环糊精在壳聚糖上 的修饰度为每 22 个壳聚糖单元结合一个环糊精. 进而, 将多壁碳纳米管分散在水中后加入环糊精修饰壳聚糖, 经室温超声振荡 $1 \mathrm{~h}$ 即可得到环糊精壳聚糖/碳纳米管超 分子组装体. 依然是通过金刚烷基团与环糊精空腔的强 键合作用将金刚烷基萠引入到壳聚糖修饰环糊精或环 糊精壳聚糖/碳纳米管超分子组装体中就可以得到它们 的萠复合物. 由于环糊精修饰壳聚糖中众多正电荷与稠 环芳烃的协同作用, 环糊精修饰壳聚糖及其碳纳米管组 装体均显示出凝聚 DNA 的能力, 但它们对 DNA 的凝聚 行为却有着明显的差异(图 10). 原子力显微镜图像显示, 环糊精修饰壳聚糖显示出中等的 DNA 凝聚能力, 能够
将 DNA 凝聚为空心的环状结构 (图 9a, 9e). 在结合了金 刚烷基萠之后, 其对 DNA 的凝聚能力有了明显的提高, 并能够将 DNA 凝聚为直径 $200 \mathrm{~nm}$ 的实心粒子(图 9b, 9f). 在相同的条件下, 环糊精壳聚糖/碳纳米管超分子 组装体则能将 DNA 凝聚为直径 $80 \mathrm{~nm}$ 的密实粒子(图 $9 \mathrm{c}, 9 \mathrm{~g}$ ), 而经环糊精壳聚糖/碳纳米管超分子组装体与金 刚烷基萠复合物处理过的 DNA 则显示为直径 $160 \mathrm{~nm}$ 的 粒子(图 9d, 9f).

\section{3 环糊精组装体对核酸的传递作用}

基因传递需要载体将基因转移或运送到细胞内并 使基因在细胞内维持其生物功能. 早期的磷酸钙转染法 转染效率较低, 且对很多细胞株无效, 因此不能满足很 多科研工作的需要, 目前较为常用的转染剂是阳离子脂 质体和阳离子聚合物. 得益于环糊精超分子组装体能够 凝聚 DNA 的功能, 基于环糊精组装体的基因转染载体 受到了化学家和生物学家的普遍关注. 例如, 将寡聚多 胺修饰环糊精化学吸附在金纳米粒子就可以构筑一种 新䓉的超分子人工非病毒类基因转染载体 ${ }^{[23]}$. 具体制 备方法为: 首先将硫辛酸与寡聚多胺修饰环糊精通过酰 胺键共价结合，再将其与嗍氢化钠和氯金酸混合，经室 温搅拌反应即可得到表面覆盖环糊精的金纳米粒子. 每 个金纳米粒子上覆盖了 37 个环糊精, 每个环糊精所占
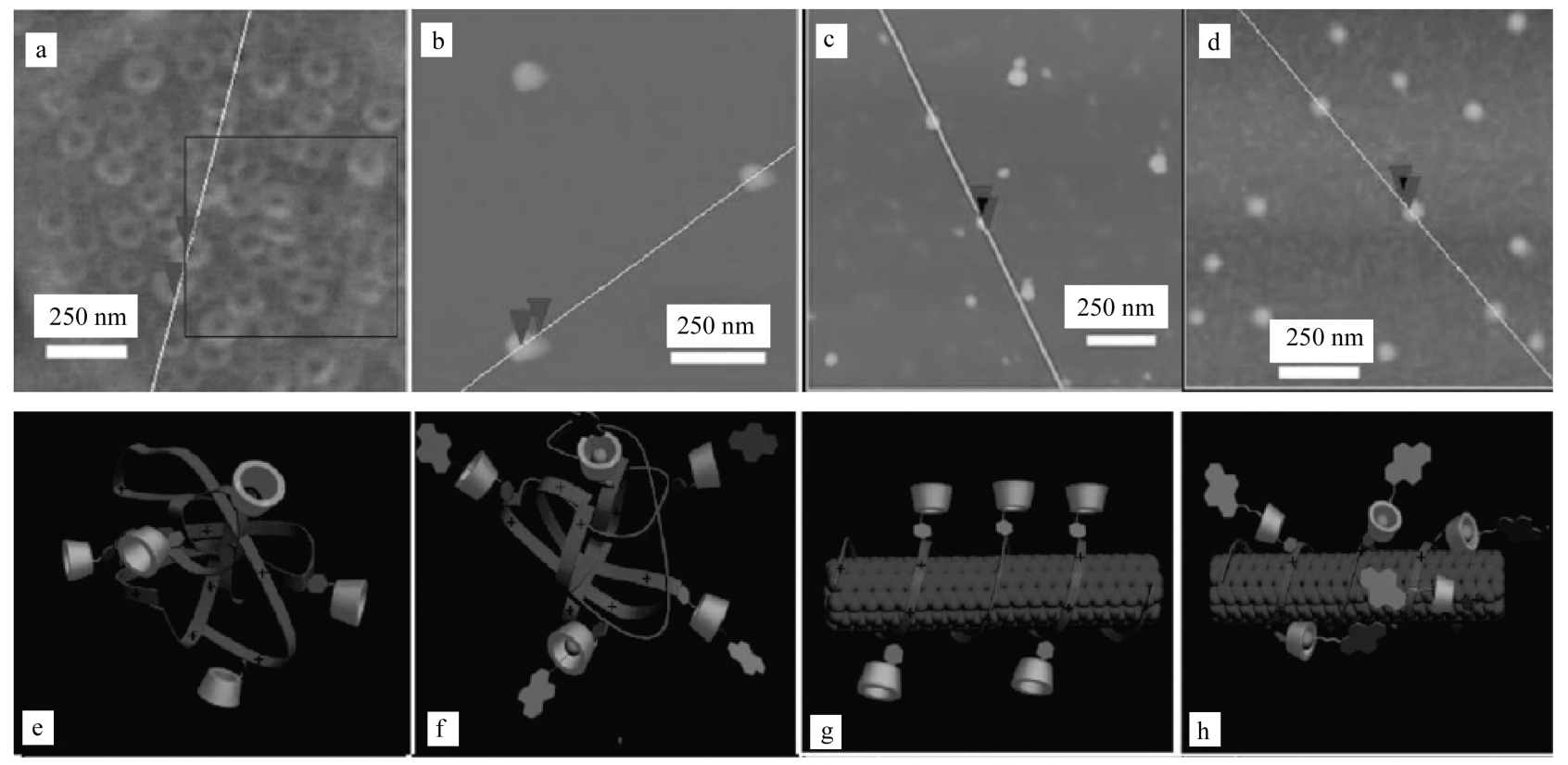

图 9 小牛胸腺 DNA $(\mathrm{a} \sim \mathrm{d})$ 分别被环糊精修饰壳聚糖(e)、环糊精修饰壳聚糖/金刚烷萠包合物(f)、环糊精修饰壳聚糖/碳纳米管超 分子组装体 $(\mathrm{g})$ 以及环糊精修饰壳聚糖/碳纳米管/金刚烷基芘( $\mathrm{h}$ )复合物凝聚后的 AFM 图像

Figure 9 AFM images of calf thymus DNA $(\mathrm{a} \sim \mathrm{d})$ condensated by (e) cyclodextrin-modified chitosan, (f) cyclodextrin-modified chitosan/adamantanylpyrene inclusion complex, (g) cyclodextrin-modified chitosan/carbon nanotube assembly and (h) cyclodextrin-modified chitosan/carbon nanotube/adamantanylpyrene conjugate 


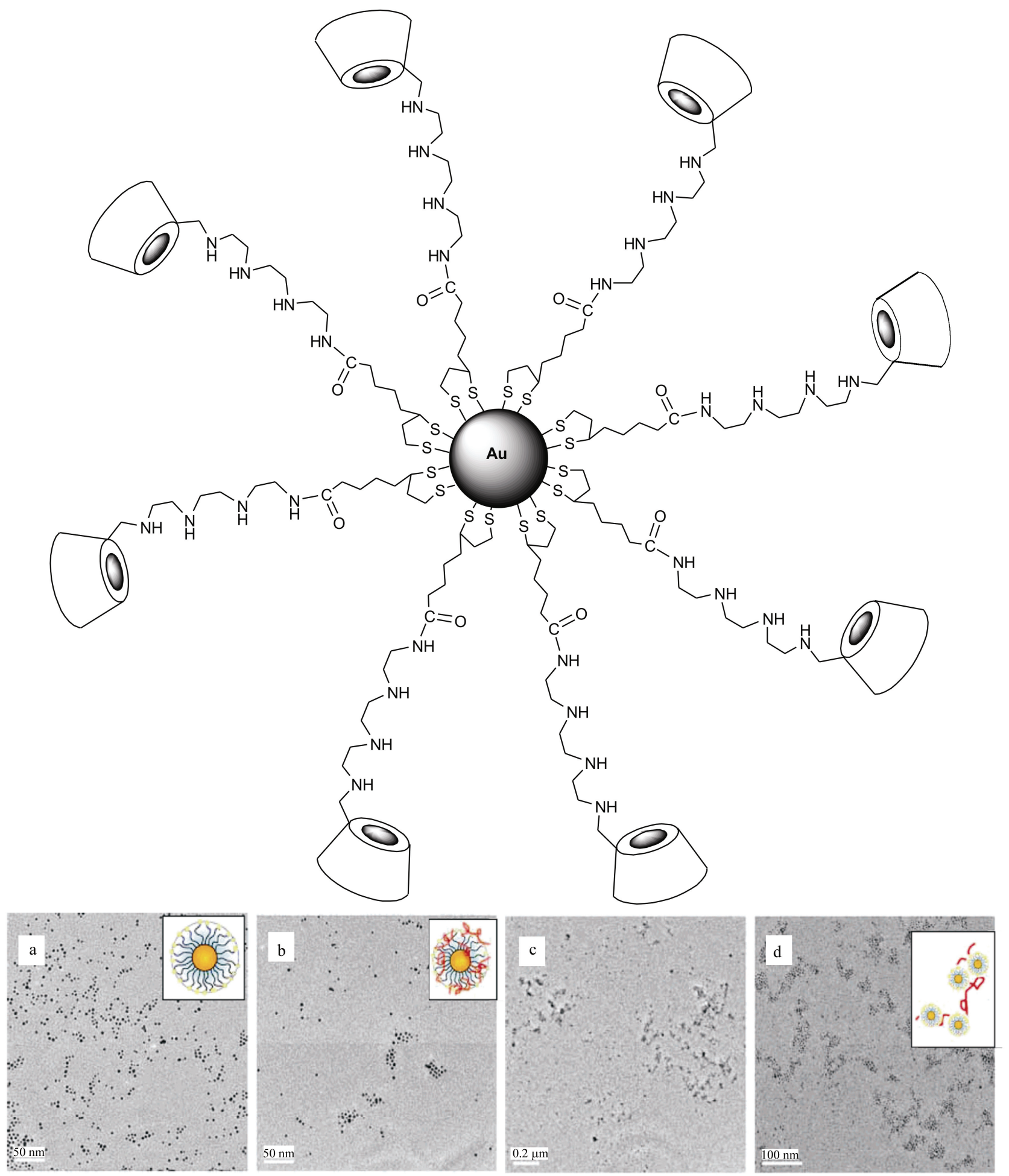

图 10 环糊精/金纳米粒子组装体的结构示意图和(a)金纳米粒子自身的 TEM 图像、(b)金纳米粒子与 DNA 以 $0.1: 1$ 比例混合后 的 TEM 图像、(c)金纳米粒子与 DNA 以 5:1 比例混合后的 TEM 图像及(d) c 图的高分辨 TEM 图像

Figure 10 Structure of cyclodextrin/gold nanoparticle assembly and TEM images of (a) cyclodextrin/gold nanoparticle assembly, (b) assembly/DNA mixture with a $m_{\text {assembly }} / m_{\mathrm{DNA}}$ ratio of $0.1: 1$, (c) assembly/DNA mixture with a $m_{\text {assembly }} / m_{\mathrm{DNA}}$ ratio of $5: 1$, and (d) enlarged high-resolution TEM image of $\mathrm{c}$

据的平均表面积为 $1.64 \mathrm{~nm}^{2}$. 透射电镜研究表明, 当环 糊精/金纳米粒子组装体与 DNA 的质量比达到 $5: 1$ 时,
DNA 出现了明显的聚集现象. 而当环糊精/金纳米粒子 组装体与 DNA 的质量比达到 $100: 1$ 时, DNA 被凝聚为 
高度紧密的粒子, 直径大于 $100 \mathrm{~nm}$ (图 10). 在评估其转 染效率和细胞毒性后我们发现, 与商品化的基因转染载 体 lipofectamine 2000 相比, 环糊精/金纳米粒子组装体 仅显示出中等的基因转染效率, 转染率为 $1.2 \% \sim 4.8 \%$, 但其细胞毒性明显低于 lipofectamine 2000.

除 DNA 外, 环糊精组装体还能有效地传递 RNA. 在首例成功的人类 RNA 干扰(RNA interference, RNAi) 临床实验中, 人转铁蛋白(human transferrin protein, $\mathrm{TF}$ ) 通过聚乙二醇( $\mathrm{PEG}$ )被共价连接到金刚烷上. 然后, 将 环糊精聚合物, 金刚烷-PEG-TF 和小干扰 RNA (siRNA) 进行超分子组装形成直径为 $70 \mathrm{~nm}$ 的粒子. 在该组装体 中, 人转铁蛋白作为癌细胞的靶向剂, PEG 起到增加纳 米粒子稳定性的作用, 金刚烷与环糊精空腔的强相互作 用可以将靶向剂固定在纳米粒子表面(图 11). 荧光显微 镜研究表明, 组装体能够有效地将 siRNA运送到肿瘤细 胞内. 肿瘤组织活检研究还发现, 接受治疗的患者细胞 中的目标蛋白的信使 RNA 表达量降低, RRM2 蛋白的表 达量也降低. 同时, 肿瘤细胞内含有大量纳米粒子的部 位也存在大量信使 RNA 片段. 这一通过环糊精超分子 组装体传递 siRNA 的研究发现使得 RNA 干扰技术在临 床上应用成为可能 ${ }^{[24]}$.

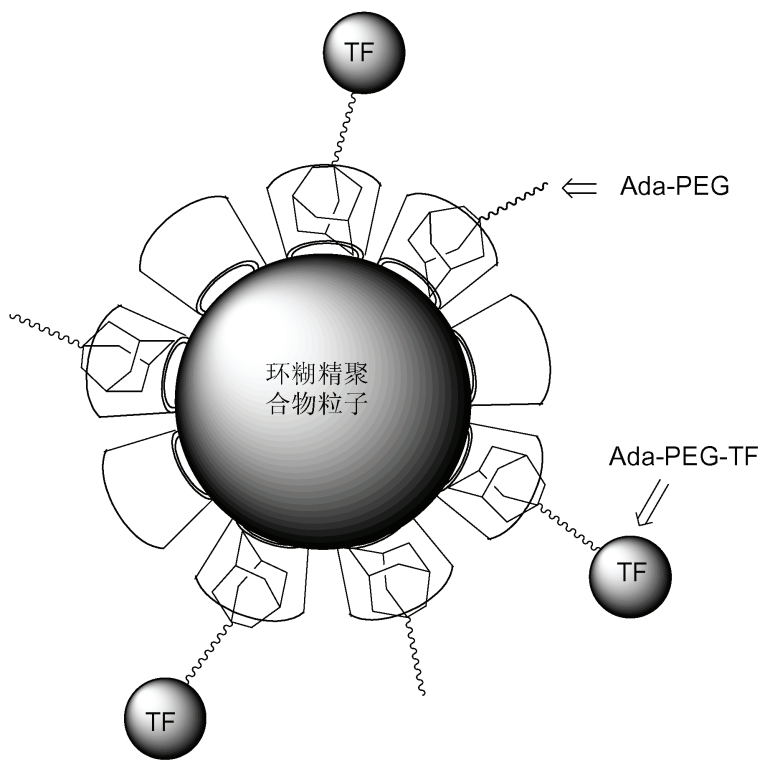

图 11 基于环糊精组装体的 RNA 传递体系

Figure 11 Structure of RNA delivery system based on cyclodextrin assembly

\section{4 环糊精组装体对核酸酶的抑制作用}

通过环糊精组装体对核酸的凝聚作用, 可以将核酸 中的酶作用位点有效地屏蔽起来，从而抑制核酸酶对核 酸的破坏作用. 例如, 2-(4'-差基苯)咪唑[5,6-f] 1,10-邻菲 咯啉(HOP) 修饰环糊精与邻菲咯啉和钉(II)离子形成的
组装体能够凝聚 DNA. 通过调节组装体加入的比例, 质 粒 DNA 能够被凝聚为环状或球状的聚集体, 其尺度由 纳米级变化至微米级. 通过这种凝聚作用, 该组装体能 够有效地抑制 DNA 切割酶和拓扑异构酶的作用. 如图 12 所示, 在没有组装体存在的条件下, DNA 会完全被 DNA 切割酶 Hind III 切开, 随着组装体的不断加入, Hind III 的 DNA 切割作用被逐渐抑制. 当组装体加入的 比例为 $200: 1$ 时, Hind III 的 DNA 切割作用被完全抑制. 除切割酶外, 组装体还能够抑制 DNA 拓扑异构酶 topomerase I 的作用. 当组装体加入的比例为 $60: 1$ 时, 组装体对拓扑异构酶 topomerase I 的抑制作用达 $28 \%{ }^{[25]}$.
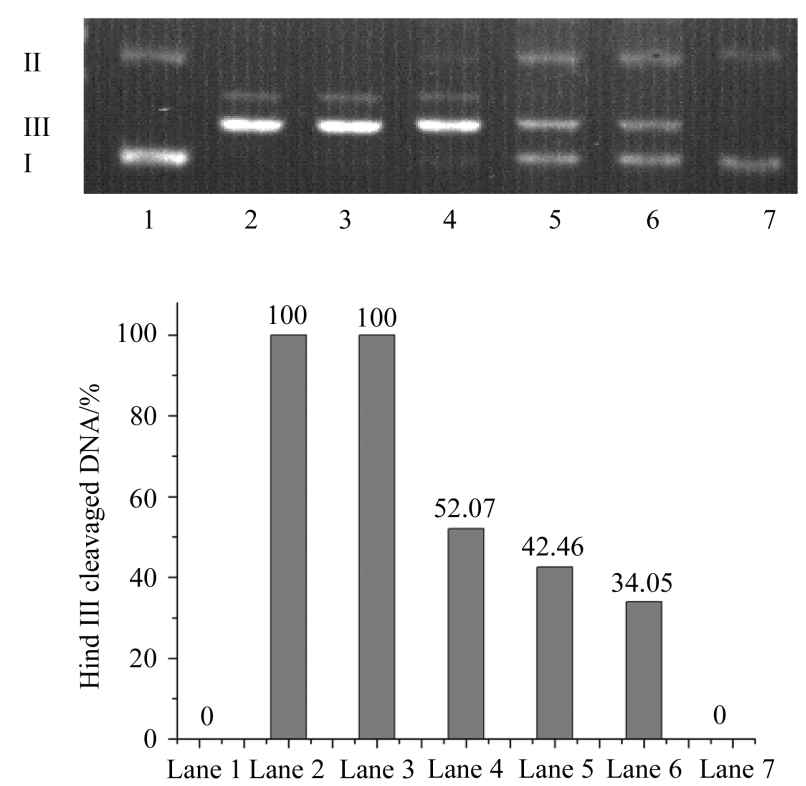

图 12 组装体对 DNA 切割酶 Hind III 的抑制作用

Figure 12 Agarose gel electrophoresis assay to investigate the inhibition ability of assembly against Hind III using plasmid pEGFP-C2

$7.5 \mathrm{ng} \cdot \mu \mathrm{L}^{-1}$ in $1 \mathrm{mmol} \cdot \mathrm{L}^{-1}$ EDTA $/ 10 \mathrm{mmol} \cdot \mathrm{L}^{-1}$ Tris buffer, $\mathrm{pH} 8.0$. Lane 1, DNA alone; lane 2, DNA and Hind III; lanes 3 7, DNA+Hind $\mathrm{III}+$ assembly ([assembly] $=150,300,450,600$ and $1500 \mathrm{ng} \cdot \mu \mathrm{L}^{-1}$, i.e. $0.074,0.147,0.221,0.295$ and $0.737 \mathrm{mmol} \cdot \mathrm{L}^{-1}$ from lane 3 to lane 7 )

\section{5 结语}

从以上研究结果可以看出, 将含有核酸作用能力的 基团与环糊精结合在一起作为构筑单元，通过非共价键 的协同作用可以构筑出系列结构新颖的超分子组装体 用于核酸的切割、凝聚、传递和对核酸酶的抑制. 在与 核酸发生相互作用时, 组装体中的环糊精空腔或功能单 元可以有效地识别核酸中的特定基团，而且众多功能单 元可以同时与核酸中的大、小沟槽以及负电荷磷酸根发 生相互作用. 通过精心的设计, 还能够对环糊精组装体 的结构及其与核酸的相互作用进行精确的调控. 得益于 环糊精的低毒性和良好的生物相容性, 我们相信环糊精 
超分子组装体作为核酸作用试剂一定会展示出非常美 好的应用前景.

\section{References}

[1] Atwood, J. L.; Steed, J. W. Encyclopedia of Supramolecular Chemistry, Marcel Dekker, New York, 2004.

[2] Wenz, G.; Han, B.-H.; Müller, A. Chem. Rev. 2006, 106, 782.

[3] Uekama, K.; Hirayama, F.; Irie, T. Chem. Rev. 1998, 98, 2045.

[4] Chen, Y.; Liu, Y. Chem. Soc. Rev. 2010, 39, 495.

[5] Bellia, F.; Mendola, L.-D.; Pedone, C.; Rizzarelli, E.; Savianoc, M.; Vecchioa, G. Chem. Soc. Rev. 2009, 38, 2756.

[6] Liu, Y.; Wang, H.; Liang, P.; Zhang, H.-Y. Angew. Chem., Int. Ed. 2004, 43, 2690

[7] Liu, Y.; Zhao, Y.-L.; Chen, Y.; Wang, M. Macromol. Rapid Commun. 2005, 26, 401.

[8] Dhar, S.; Senapati, D.; Das, P. K.; Chattopadhyay, P.; Nethaji, M.; Chakravarty, A. R. J. Am. Chem. Soc. 2003, 125, 12118.

[9] Liu, Y.; Wang, H.; Chen, Y.; Ke, C.-F.; Liu, M. J. Am. Chem. Soc. 2005, 127, 657

[10] Frens, G. Nat. Phys. Sci. 1973, 241, 20.

[11] Sun, Y.-P.; Lawson, G. E.; Huang, W.-J.; Wright, A. G.; Moton, D. K. Macromolecules 1999, 32, 8747.

[12] Nelson, A.; Belitsky, J. M.; Vidal, S.; Joiner, C. S.; Baum, L. G.; Stoddart, J. F. J. Am. Chem. Soc. 2004, 126, 11914.

[13] Ooya, T.; Choi, H. S.; Yamashita, A.; Yui, N.; Sugaya, Y.; Kano,
A.; Maruyama, A.; Akita, H.; Ito, R.; Kogure, K.; Harashima, H. J. Am. Chem. Soc. 2006, 128, 3852.

[14] Yamashita, A.; Choi, H.-S.; Ooya, T.; Yui, N.; Akita, H.; Kogure, K.; Harashima, H. ChemBioChem 2006, 7, 297.

[15] Li, J.; Yang, C.; Li, H.-Z.; Wang, X.; Goh, S.-H.; Ding, J.-L.; Wang, D.-Y.; Leong, K.-W. Adv. Mater. 2006, 18, 2969.

[16] Liu, Y.; Ke, C.-F.; Zhang, H.-Y.; Wu, W.-J.; Shi, J. J. Org. Chem. 2007, 72, 280.

[17] Ke, C.-F.; Hou, S.; Zhang, H.-Y.; Liu, Y.; Yang, K.; Feng, X.-Z. Chem. Commun. 2007, 3374.

[18] Ikeda, T.; Yoshida, K.; Schneider, H.-J. J. Am. Chem. Soc. 1995, 117,1453

[19] Liu, Y.; Yu, L.; Chen, Y.; Zhao, Y.-L.; Yang, H. J. Am. Chem. Soc. 2007, 129, 10656.

[20] Yu, M.; Zu, S.-Z.; Chen, Y.; Liu, Y.-P.; Han, B.-H.; Liu, Y. Chem. Eur. J. 2010, 16, 1168

[21] Zhao, X.; Johnson, J. K. J. Am. Chem. Soc. 2007, 129, 10438.

[22] Liu, Y.; Yu, Z.-L.; Zhang, Y.-M.; Guo, D.-S.; Liu, Y.-P. J. Am. Chem. Soc. 2008, 130, 10431.

[23] Wang, H.; Chen, Y.; Li, X.-Y.; Liu, Y. Mol. Pharm. 2007, 4, 189.

[24] Davis, M. E.; Zuckerman, J. E.; Choi, C. H. J.; Seligson, D.; Tolcher, A.; Alabi, C. A.; Yen, Y.; Heidel, J. D.; Ribas, A. Nature 2010, 464, 1067.

[25] Liu, Y.; Chen, Y.; Duan, Z.-Y.; Feng, X.-Z.; Hou, S.; Wang, C.; Wang, R. ACS Nano 2007, 1, 313. 